\title{
The Arctic response to remote and local forcing of black carbon
}

\author{
M. Sand ${ }^{1}$, T. K. Berntsen ${ }^{1}$, J. E. Kay ${ }^{2}$, J. F. Lamarque ${ }^{2}$, Ø. Seland ${ }^{3}$, and A. Kirkevåg ${ }^{3}$ \\ ${ }^{1}$ Department of Geosciences, Meteorology and Oceanography Section, University of Oslo, Oslo, Norway \\ ${ }^{2}$ National Center for Atmospheric Research, Boulder, Colorado, USA \\ ${ }^{3}$ Norwegian Meteorological Institute, Oslo, Norway \\ Correspondence to: M. Sand (maria.sand@geo.uio.no)
}

Received: 15 June 2012 - Published in Atmos. Chem. Phys. Discuss.: 26 July 2012

Revised: 13 December 2012 - Accepted: 18 December 2012 - Published: 9 January 2013

\begin{abstract}
Recent studies suggest that the Arctic temperature response to black carbon (BC) forcing depend strongly on the location of the forcing. We investigate how atmospheric BC in the mid-latitudes remotely influence the Arctic climate, and compare this with the response to atmospheric $\mathrm{BC}$ located in the Arctic itself. In this study, idealized climate simulations are carried out with a fully coupled Earth System Model, which includes a comprehensive treatment of aerosol microphysics. In order to determine how BC transported to the Arctic and $\mathrm{BC}$ sources not reaching the Arctic impact the Arctic climate, atmospheric $\mathrm{BC}$ concentrations are scaled up in the mid-latitudes $\left(28-60^{\circ} \mathrm{N}\right)$ and in the Arctic $\left(60-90^{\circ} \mathrm{N}\right)$, respectively. Estimates of the impact on the Arctic energy budget are represented by analyzing radiation fluxes at the top of the atmosphere and at the surface, surface turbulent fluxes, and meridional heat transport in the atmosphere. Our calculations show that increased BC forcing in the Arctic atmosphere reduces the surface air temperature in the Arctic with a corresponding increase in the sea-ice fraction, despite the increased planetary absorption of sunlight. The analysis indicates that this effect is due to a combination of a weakening of the northward heat transport caused by a reduction in the meridional temperature gradient and a dimming at the surface. On the other hand we find that $\mathrm{BC}$ forcing at the mid-latitudes warms the Arctic surface significantly and decreases the sea-ice fraction. Our model calculations indicate that atmospheric $\mathrm{BC}$ forcing outside the Arctic may be more important for the Arctic climate change than the forcing in the Arctic itself. These results suggest that mitigation strategies for the Arctic climate should also address BC sources in locations outside the Arctic even if they do not contribute much to $\mathrm{BC}$ in the Arctic.
\end{abstract}

\section{Introduction}

Arctic temperatures have increased at a rate about twice as fast as the global mean rate during the last decades (AMAP, 2011a). Many inter-related factors arising both from internal climate variability and external climate forcing could have contributed to this greater-than-global Arctic warming. Strong local feedbacks (snow/ice-albedo, clouds) enhance the warming by long-lived greenhouse gases and other forcings. In addition increased poleward heat transport and absorbing aerosols (black carbon) may have contributed to the amplification (IPCC, 2007). Accompanied by the temperature increase, the Arctic has experienced a longer melt season with an earlier spring melt and a decrease in the sea-ice extent (AMAP, 2011a). Black carbon (BC) aerosols absorb solar radiation and heat the surrounding air. This direct effect of BC may be potentially large in the Arctic, as the absorbing aerosols are located over highly reflective snow/ice surfaces (Pueschel and Kinne, 1995; Hansen and Nazarenko, 2004). In general added atmospheric heat will increase the downward fluxes of longwave radiation and sensible heat, and thus warm the underlying surface. However, models and measurements (Koch et al., 2009a) indicate that BC aerosols are located mainly the free troposphere and in may further stabilize the Arctic atmosphere, thereby limiting the downward flux of sensible heat and the potential surface warming.

$\mathrm{BC}$ aerosols in the Arctic originate from emissions mainly at mid-latitudes that are transported northwards (Barrie, 1986; Law and Stohl, 2007). Sources of BC include both anthropogenic sources (e.g. energy and industrial production, domestic combustion and transport) and natural sources (forest and grassfires induced from lightening). During winter the northward transport is strongest, and the lifetime of $\mathrm{BC}$ 
in the atmosphere is longer, causing a maximum BC concentration in the Arctic in late winter and spring (Sharma et al., 2006). The elevated $\mathrm{BC}$ concentrations also extend into the melting season, which could make BC particularly important in the Arctic. BC aerosols affect the atmospheric temperature gradients and can therefore change the atmospheric heat transport. In addition, BC aerosols can have an indirect effect on clouds by influencing the cloud properties and cloud lifetime via microphysical interactions. $\mathrm{BC}$ can also affect the distribution of clouds by changing the stability of the atmosphere, often referred to as the semi-direct effect (Koch and Genio, 2010).

Absorbing aerosols affect the climate in numerous ways and thus there are large uncertainties in estimating the net BC forcing. While the direct radiative forcing of $\mathrm{BC}$ increases with increasing altitude of the BC perturbation (e.g. Samset and Myhre, 2011), models indicate that the climate efficacy (surface temperature response per unit forcing) is decreasing with increasing altitude of the BC (Hansen et al., 2005; Ban-Weiss et al., 2011). Because of the short lifetime of $\mathrm{BC}$ compared to well-mixed greenhouse gases, $\mathrm{BC}$ has a potential for short-term climate control strategies (Hansen et al., 2000; Levy et al., 2008; Jacobson, 2010; Shindell et al., 2012). In order to identify the best options for emission reductions there is a need for improving the understanding of the role of BC aerosols in the Arctic (AMAP, 2011b) and how the response of the Arctic climate depends on the location of BC forcing. Shindell (2007) demonstrated that the climate response in the Arctic is highly correlated with mid-latitude forcing during non-summer seasons, due to the large-scale dynamics influencing the Arctic climate. In these months the Arctic surface temperature response can show opposite signs to the local forcing. Results from Menon et al. (2002) also indicate that forcing from $\mathrm{BC}$ can have a climate impact away from the forcing area, by local atmospheric heating and dynamical transport. Shindell and Faluvegi (2009) perturbed forcings by enhancing the concentrations of $\mathrm{BC}$ aerosols in different latitude bands and found that for the Arctic latitude band, the Arctic surface air temperature (SAT) decreased, despite a positive forcing at the top of the atmosphere, i.e. a regional negative climate efficacy. Shindell and Faluvegi attributed this mainly to a reduction in the poleward heat flux following increased absorption of incoming solar radiation by $\mathrm{BC}$ and local heating in the free troposphere. For positive direct forcing by $\mathrm{BC}$ aerosols in the mid-latitude band the Arctic surface temperature response was positive (warming).

With the increasing focus on the effect of $\mathrm{BC}$ aerosols on the Arctic climate, there is a need to test the robustness of the findings by Shindell and Faluvegi by reproducing parts of the experiment with a different climate model; to analyze the Arctic climate response to $\mathrm{BC}$ perturbations in the Arctic $\left(60-90^{\circ} \mathrm{N}\right)$ and northern mid-latitude $\left(28-60^{\circ} \mathrm{N}\right)$ atmosphere respectively. Expanding on the previous study, we want to understand and quantify the contribution from the different processes that are important for forcing by compo- nents absorbing short-wave radiation and the response in the Arctic, including an analysis of the perturbation to the energy budget of the Arctic atmosphere. Idealized climate simulations with increased $\mathrm{BC}$ concentrations in the two separate latitude bands have been performed with a fully coupled earth system model, the NorESM, to include dynamic responses, feedbacks from sea ice cover and sea surface temperatures (SSTs). The atmospheric model includes a comprehensive treatment of aerosol microphysics, accounting for aerosol nucleation, condensation, coagulation and cloud processing, and calculates the conversion of $\mathrm{BC}$ to a hydrophilic state where it can be scavenged by precipitation (Kirkevåg et al., 2008; Seland et al., 2008). The wet deposition is calculated in full integration with the cloud and precipitation schemes. The two experiments are compared with a control run to analyze the response in the Arctic temperatures to the two forcings, including changes in sea-ice, cloud cover and the meridional energy transport into the Arctic.

\section{Data and methods}

\subsection{NorESM}

The climate model used in this study is the Norwegian Earth System Model, NorESM (Bentsen et al., 2012; Iversen et al., 2012), to a large extent based on the Community Climate System Model CCSM4.0 (Gent et al., 2011), developed at the National Center for Atmospheric Research (NCAR). The model is run fully coupled with an atmospheric model, an ocean model, a land model and a sea-ice model. The atmospheric part of NorESM, CAM4-Oslo, includes a scheme for calculating the life-cycle of aerosols along with their optical and physical properties and is thoroughly described in Kirkevåg et al. (2008); Seland et al. (2008) and Kirkevåg et al. (2012). The ocean model in NorESM, MICOM, is an updated version from the Bergen Climate Model, BCM (Furevik et al., 2003; Otterå et al., 2009). The sea-ice model (CICE4) and the land model (CLM4) in NorESM are the same as in CCSM4.0, except that the deposition of BC and mineral dust aerosols onto snow and sea-ice are given by CAM4-Oslo instead of using pre-calculated deposition fields as is done in CCSM4.0.

\section{Aerosols in NorESM}

The prognostic aerosols and aerosol precursors in CAM4Oslo include sea-salt, mineral dust, dimethyl sulfide (DMS), sulphur dioxide, sulphate, $\mathrm{BC}$ and particulate organic matter $(\mathrm{OM})$ and they interact online with the cloud microphysics, radiation and meteorology in the model. The present-day (2000) emissions are taken from Lamarque et al. (2010). Aerosol optical properties and size distributions (for calculation of cloud droplet number concentrations, CDNC) are calculated by use of look-up tables, where the entries in the tables are calculated by a single air parcel model for a wide 
range of atmospheric conditions. Both the direct effect and the first and second indirect effects are calculated. The direct effect of aerosols is caused by the scattering and absorption of radiation, mainly in the shortwave spectrum. The indirect effects of aerosols are due to their interaction with clouds, by acting as cloud condensation nuclei or ice nuclei. The aerosols can change the number and size of cloud droplets (the first indirect effect; Twomey, 1977) and the lifetime of clouds (the second indirect effect; Albrecht, 1989). In the model the only process which causes the second indirect effect is the auto-conversion of cloud droplets to precipitation in warm clouds (Hoose et al., 2009). Absorbing aerosols embedded in or near a cloud layer may also reduce the cloud cover by heating the air and promoting cloud evaporation, leading to a positive semi-direct effect (Hansen et al., 1997). The semi-direct effect of BC can also be negative (e.g. if the $\mathrm{BC}$ increase the static stability). In the look-up tables, size distributed aerosol number concentrations and composition, as well as bulk optical properties, have been calculated from basic physico-chemical processes. The concentrations are tagged according to size mode (nucleation, aitken, accumulation, coarse) and production mechanism (nucleation, condensation, coagulation, aqueous chemistry).

$\mathrm{BC}$ is emitted from biomass burning, fossil fuel combustion and biofuels. The total annual emissions of $\mathrm{BC}$ are 7.7 $\mathrm{Tg}^{-1}$. When emitted from biomass burning, BC and $\mathrm{OM}$ are assumed internally mixed with each other. Primary $\mathrm{BC}$ particles are emitted as nucleation and accumulation mode $\mathrm{BC}$ and internally mixed aitken mode $\mathrm{OM}$ and $\mathrm{BC}$. Externally mixed $\mathrm{BC}$ is hydrophobic, and turns gradually into hydrophilic, internally mixed aerosols by condensation of gaseous sulphate, or by coagulation with sulphate, sea-salt or OM. BC is removed from the atmosphere by dry deposition and wet removal, although the latter process dominates the total numbers.

\subsection{Experimental setup}

The model is set up with a Finite Volume dynamical core with 26 vertical layers and with a $1.9 \times 2.5^{\circ}$ horizontal grid resolution. For each simulation the model is run $60 \mathrm{yr}$ from a $140 \mathrm{yr}$ spin-up with the same initial conditions and the same present-day emissions. In the two perturbed simulations the model is run with the same emissions as the control run, but in the radiation code the $\mathrm{BC}$ concentrations are multiplied by a factor of 10 in the Arctic $\left(60-90^{\circ} \mathrm{N}\right.$; "the ARC experiment") and mid-latitudes ( $28-60^{\circ} \mathrm{N}$; "the MID experiment"), respectively. The BC concentrations have been multiplied by 10 in order to get a statistically significant climate signal in the $60 \mathrm{yr}$ simulations. It is worth noting that the scaling is larger than in previous studies (e.g. Shindell and Faluvegi, 2009; Koch et al., 2009b), however, many previous studies have used models with a simpler q-flux slab ocean, while in this study we use a fully coupled ocean. A substantial scaling is necessary to obtain a robust result, however, it should not be too large so that the underlying assumption that the response is close to linear is not valid. Hansen et al. (2005) found that the response was close to linear for scaling giving a global aerosol RF of the order of $1 \mathrm{~W} \mathrm{~m}^{-2}$. The global RF following the scaling applied here is always below $1.5 \mathrm{~W} \mathrm{~m}^{-2}$ (cf. Sect. 3.2). A recent study by Chung et al. (2012) shows that the direct radiative forcing from absorbing carbonaceous aerosols could be a factor 2 higher than previously estimated (e.g. Forster et al., 2007). In order to calculate the radiative forcing at the TOA with identical meteorology for each simulation, the same 3 experiments $(1 \times \mathrm{BC}, 10 \times \mathrm{BC}$ mid latitudes and $10 \times \mathrm{BC}$ in the Arctic) is repeated in separate $5 \mathrm{yrs}$ offline simulations. In the offline simulations the meteorology is driven by prescribed NCAR CAM4 aerosols, CDNC and greenhouse gases and is not affected by the perturbation in the $\mathrm{BC}$ concentrations. In the online $60 \mathrm{yr}$ simulations on the other hand, the aerosol, cloud and radiation is fully coupled so the aerosols are allowed to affect the meteorology and thus the meteorology in the online simulations is different from the offline simulations. The $\mathrm{BC}$ concentrations in the offline and the online simulations are comparable in size (differ $13 \%$ in the Arctic and $6 \%$ in the mid latitudes), so the two simulations set-ups can be used side-by-side. Note that only atmospheric BC has been perturbed in this study and the radiative forcing and climate response from BC deposition on snow and ice (e.g. Flanner et al., 2007) lie outside the scope of this study.

\subsection{The Arctic energy budget}

To understand the responses in the Arctic climate due to the BC perturbations we analyze the energy budget of the Arctic atmosphere in detail. The forcing and the temperature response in the Arctic influence the meridional temperature gradient, which may dampen or strengthen the atmospheric heat transport into the Arctic. When studying Arctic climate change and local feedbacks, it is important to include the energy transport because of the strong coupling between Arctic feedback mechanisms and the energy transport into the Arctic (Hwang et al., 2011). The northward heat transport (NHT) is defined as the net atmospheric flux of heat from lower latitudes into the Arctic region. Following Porter et al. (2010) and Kay et al. (2012a) the atmospheric NHT can be calculated by looking at the energy budget for an atmospheric column,

$\mathrm{NHT}=\frac{\mathrm{d} E}{\mathrm{~d} t}-F_{\mathrm{TOA}}+F_{\mathrm{SURF}}$

$E$ is the atmospheric energy, $F_{\mathrm{TOA}}$ is the net energy budget at the top of the atmosphere and $F_{\mathrm{SURF}}$ is the net energy budget at the surface. $F_{\text {TOA }}$ is defined as:

$F_{\mathrm{TOA}}=\mathrm{SW}_{\mathrm{TOA}}+\mathrm{LW}_{\mathrm{TOA}}$ 
$\mathrm{SW}_{\mathrm{TOA}}$ is the net incoming shortwave radiation and $\mathrm{LW}_{\mathrm{TOA}}$ is the net outgoing long wave radiation. $F_{\mathrm{SURF}}$ is defined as:

$$
F_{\text {SURF }}=\mathrm{SW}_{\mathrm{SURF}}+\mathrm{LW}_{\mathrm{SURF}}+\mathrm{LHFLX}+\mathrm{SHFLX}
$$

$\mathrm{SW}_{\text {SURF }}$ is the net surface shortwave radiation, $\mathrm{LW}_{\mathrm{SURF}}$ is the net surface long wave radiation, LHFLX is the latent heat flux and SHFLX is the sensible heat flux. The model is run with a fully coupled ocean model allowing for changes in the heat transport in the ocean. With the atmospheric perspective adopted here, the impact of this will be represented by a change in the surface fluxes. Since the LHFLX model output (LHFLX $\left.{ }_{\text {output }}\right)$ does not include the latent heat released when water droplets freeze and form snow that reach the surface, this has been calculated using

$$
\text { LHFLX }=-(\text { LHf } \cdot \rho \cdot \text { PRECsnow })-\text { LHFLX }_{\text {output }}
$$

LHf is the latent heat of fusion (in $\mathrm{J} \mathrm{kg}^{-1}$ ), $\rho$ is the density of water (in $\mathrm{kg} \mathrm{m}^{-3}$ ) and $\mathrm{PREC}_{\text {snow }}$ is the snow precipitation rate (water equivalent) (in $\mathrm{m} \mathrm{s}^{-1}$ ).

We use the same sign convention as Kay et al. (2012a), with all terms in $F_{\mathrm{TOA}}$ defined positive when the atmosphere gains energy and all term in $F_{\text {SURF }}$ defined positive when the surface gains energy; i.e. positive downward both for the $F_{\mathrm{TOA}}$ and the $F_{\mathrm{SURF}}$. For annual averages, the energy storage term is small and negligible compared to $F_{\mathrm{TOA}}, F_{\mathrm{SURF}}$ and NHT. The net atmospheric NHT can then be calculated as a residual of the remaining terms, $F_{\mathrm{TOA}}$ and $F_{\mathrm{SURF}}$.

\section{Simulated black carbon}

\subsection{BC concentrations}

The simulated annual mean BC column burden, the zonal annual mean $\mathrm{BC}$ concentrations and the Arctic monthly mean $\mathrm{BC}$ column burden for the reference run are shown in Fig. 1 . Because of the short lifetime of $\mathrm{BC}$ on the order of days, the concentrations are largest close to the source regions near the surface; over densely populated and industrialized areas in China, Europe and the United States and over areas with biomass burning in Africa and South America. In the Arctic, on the other hand, the concentrations increase with height and the maximum concentrations are found in the middle troposphere (Fig. 1b). The strong static stability in the Arctic suppresses turbulent mixing between the surface and the upper troposphere, in particular during winter and early spring. The global mean BC column burden in the model is $280 \mu \mathrm{g} \mathrm{m}^{-2}$. This is in good agreement with the multimodel mean value of $250 \mu \mathrm{g} \mathrm{m}^{-2}$ in the AeroCom model intercomparison project (Schulz et al., 2006). Averaged in each latitude band, the BC column burden is $180 \mu \mathrm{g} \mathrm{m}^{-2}$ in the Arctic and $360 \mu \mathrm{g} \mathrm{m}^{-2}$ in the mid-latitudes. In the model, the $\mathrm{BC}$ concentrations have a seasonal pattern in the Arctic, with a build up during winter, due to a combination of stronger northward transport and longer lifetime of
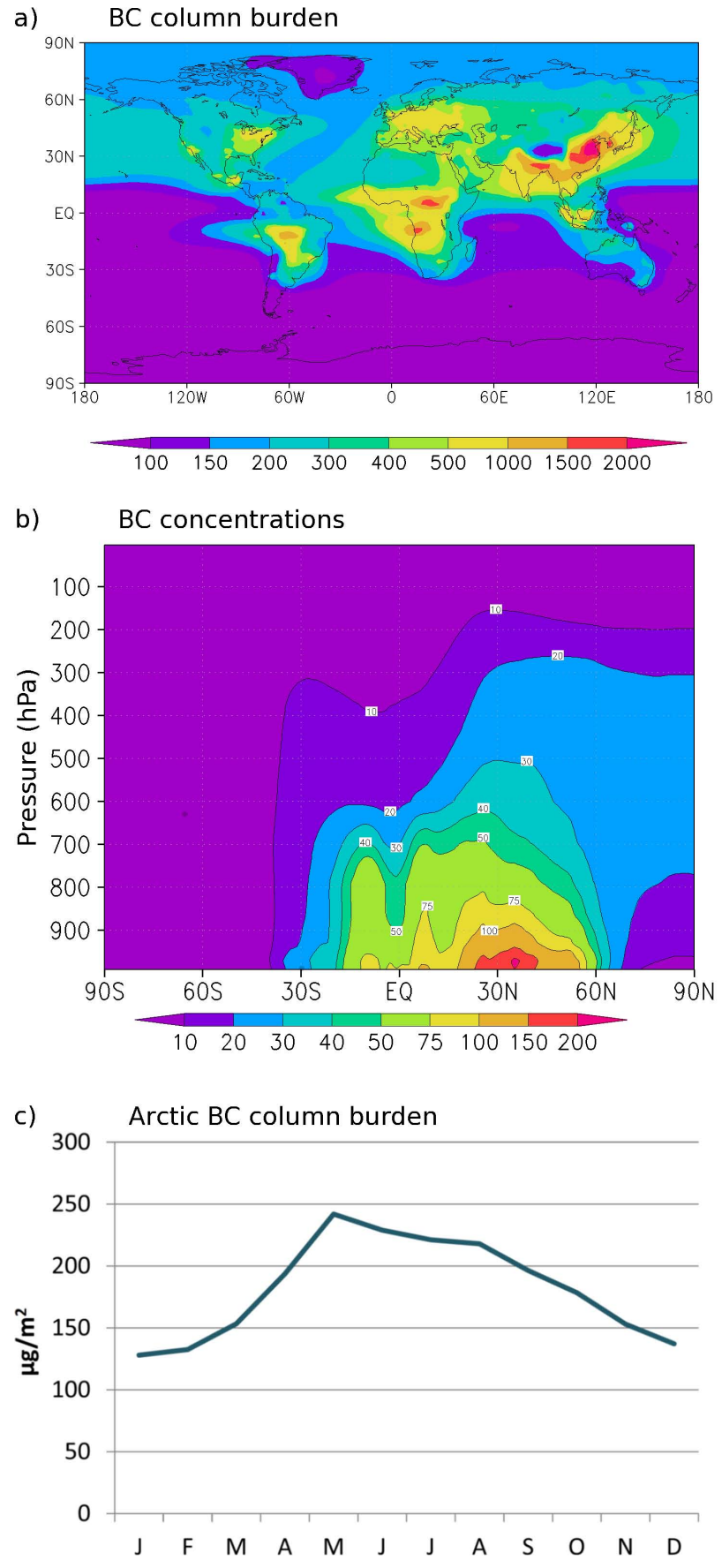

Fig. 1. (a) Annual mean BC column burden (in $\mu \mathrm{g} \mathrm{m} \mathrm{m}^{-2}$ ); (b) zonal annual mean $\mathrm{BC}$ concentration (in $\mathrm{ng} \mathrm{m}^{-3}$ ) and (c) Arctic monthly mean BC column burden (in $\mu \mathrm{g} \mathrm{m}^{-2}$ ) for the CONTROL run with 2000 emissions.

the aerosols (Bauer et al., 2010; Liu et al., 2011; Lund and Berntsen, 2012). In the model this leads to a maximum in the $\mathrm{BC}$ column burden in the Arctic during May.

Koch et al. (2009a) compared the vertical distribution of $\mathrm{BC}$ in different models to observations from aircraft 
campaigns. They showed that the models (including a predecessor of the NorESM model, labeled UiOGCM in Koch et al., 2009a) in general underestimate high latitude BC concentrations in the lower troposphere and tend to overestimate the $\mathrm{BC}$ concentrations in the upper troposphere. A comparison of the monthly mean observed and modeled surface $\mathrm{BC}$ concentrations of three Arctic stations for the years 2005 and 2006 is included in Fig. 2a). The measurements from Barrow are from the NOAA GMD database (www.esrl.noaa.gov/gmd) and measurements from Zeppelin station are provided by K. Eleftheriadis and S. Vratolis (Eleftheriadis et al., 2009) from the EBAS database (http://ebas.nilu.no). The measurements for the Alert station are provided by S. Sharma at Environment Canada. The concentrations show a wintertime build-up of Arctic haze and a summertime minimum. The variability in the observed concentrations are greater than in the modeled concentrations as should be expected since the observations are point sources from $2 \mathrm{yr}$ only, while the modeled concentrations constitutes a climatology for a larger grid cell box $\left(\sim 2^{\circ}\right)$. The May 2006 measurement from the Zeppelin station is an outlier, as this was a week coincident with an extreme weather situation and agricultural fires, causing a direct transport of agricultural fires from Eastern Europe to the Zeppelin station and record-high air pollution levels in the European Arctic (Stohl et al., 2007). The modeled surface concentrations are significantly underestimated during winter and early spring. There are a number of possible causes for the underestimation of $\mathrm{BC}$ at ground level, such as too low $\mathrm{BC}$ emissions at high latitudes, too rapid aging and/or too stable boundary layer in the model. The anthropogenic emissions, including domestic wood burning, are included as annual averages, and emissions from flaring, a potentially important high latitude source, is not included at all due to lack of emission data. Generally, climate models tend to underestimate the wintertime surface BC concentrations in the Arctic compared to measurements (Shindell et al., 2008). NorESM has a larger aerosol absorption optical depth at higher latitudes compared to most other models in the model comparison study AEROCOM (Myhre et al., 2012; Samset et al., 2012). The model may overestimate BC concentrations in the Arctic free troposphere, but the vertical profile of Arctic $\mathrm{BC}$ is not well known due to sparse vertical measurements. In terms of the climate response to direct absorption by $\mathrm{BC}$ aerosols which is the focus here, the large underestimation of surface BC at high latitudes during the dark season is of minor importance. During the summer season and early autumn (May-October) the modeled surface concentrations are within the range of the observed concentrations.

Modeled and observed monthly mean BC surface concentrations for 11 stations at mid latitudes are shown in Fig. 2b). The observed concentrations are from the EMEP database (http://www.emep.int) for 2002/2003. The model underestimates the observed concentrations for most stations particularly during the winter season and lacks a pronounced seasonal variation. For a further model validation of $\mathrm{BC}$ the
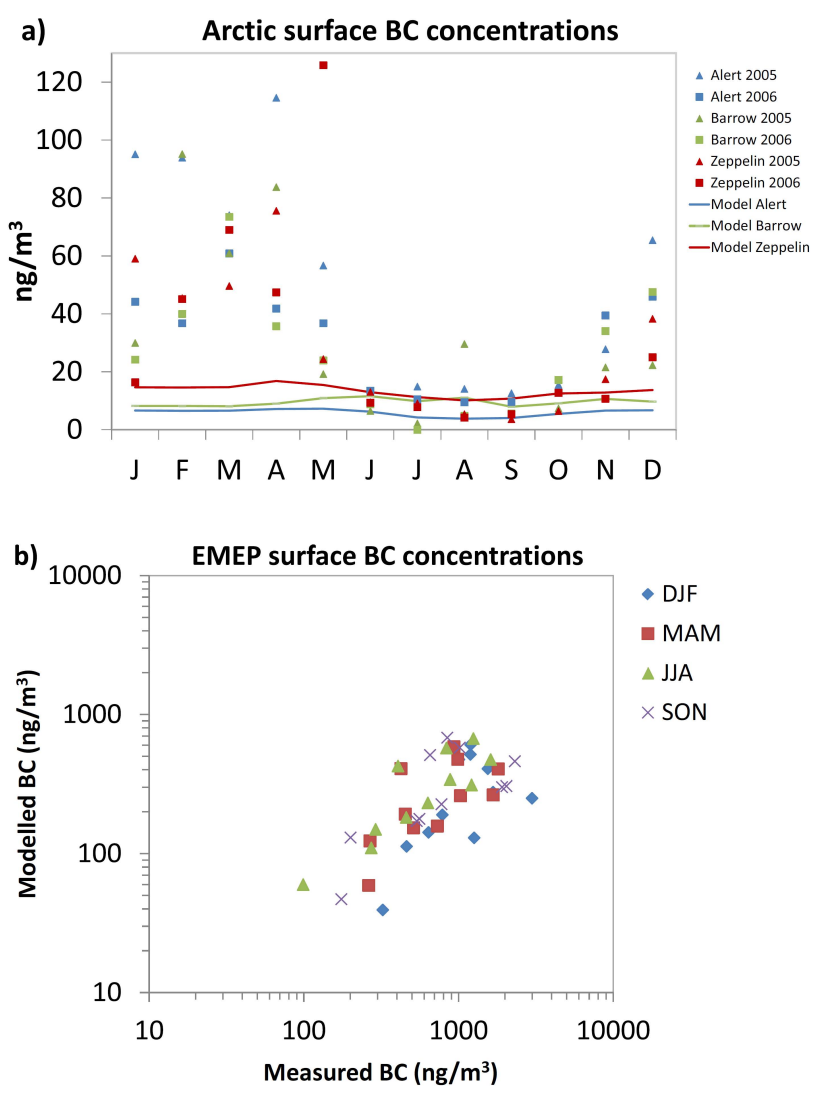

Fig. 2. (a) Monthly mean observed (markers) and modeled (lines) surface BC concentrations from 3 Arctic stations 2005/2006; (b) seasonal mean observed and modeled surface BC concentrations in Europe (from the EMEP 2002/2003 campaign). The modeled surface concentrations are from the control run. All units in $\mathrm{ng} \mathrm{m}^{-3}$.

reader is referred to Kirkevåg et al. (2012). In Kirkevåg et al. (2012) it is shown that the NorESM model with 2000 emissions underestimates surface $\mathrm{BC}$ concentrations globally by $36 \%$.

\section{2 $\mathrm{BC}$ forcing in the Arctic and the mid-latitudes}

The direct and indirect radiative forcing of $\mathrm{BC}$ is calculated as the difference in incoming and outgoing solar radiation at the TOA between the offline perturbed runs and the control run. The annual $28-60^{\circ} \mathrm{N}$ mean direct radiative forcing at the TOA for the MID experiment is estimated to $7.3 \mathrm{~W} \mathrm{~m}^{-2}$ $\left(1.5 \mathrm{~W} \mathrm{~m}^{-2}\right.$ global average) and the indirect forcing is estimated to $0.2 \mathrm{~W} \mathrm{~m}^{-2}\left(0.03 \mathrm{~W} \mathrm{~m}^{-2}\right)$. For ARC experiment the estimated annual $60-90^{\circ} \mathrm{N}$ mean direct radiative forcing at the TOA is $6.0 \mathrm{~W} \mathrm{~m}^{-2}\left(0.4 \mathrm{~W} \mathrm{~m}^{-2}\right)$ and the indirect local forcing at the TOA is $0.1 \mathrm{~W} \mathrm{~m}^{-2}\left(0.01 \mathrm{~W} \mathrm{~m}^{-2}\right)$. The geographical distribution of the $\mathrm{BC}$ annual mean direct radiative forcing from ARC and MID is shown in Fig. 3. The distribution depends on the column burden of $\mathrm{BC}$, but also on the albedo of the underlying surface, vertical distribution 


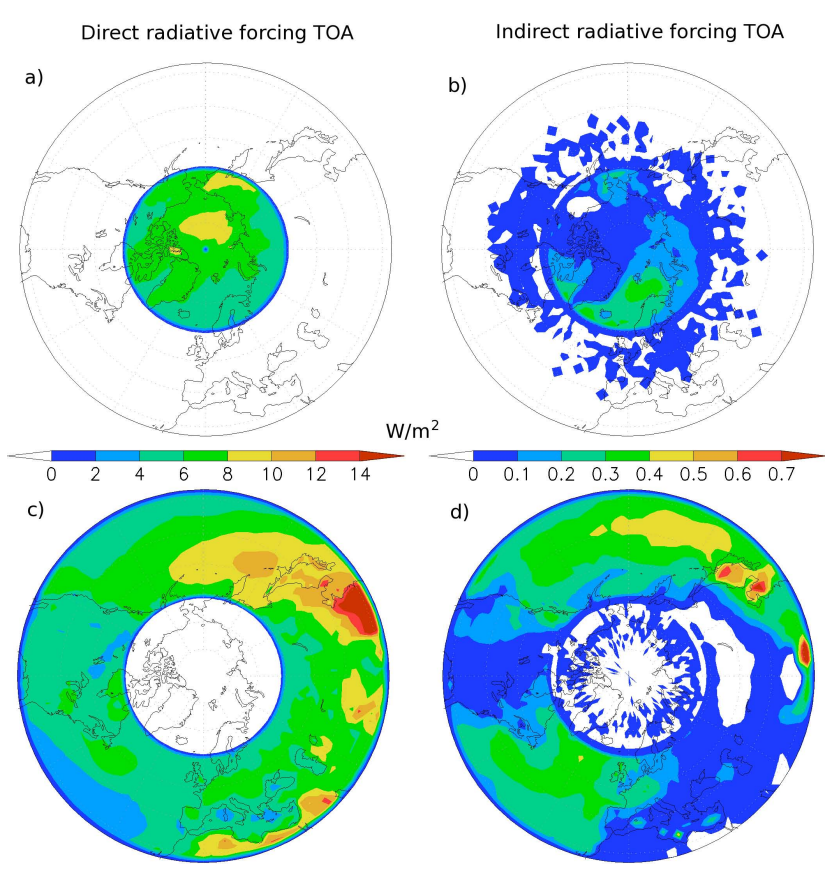

Fig. 3. Annual mean direct radiative forcing (left) and indirect radiative forcing (right) at the TOA for the ARC-CONTROL (top) and the MID-CONTROL (bottom). All units in $\mathrm{W} \mathrm{m}^{-2}$.

of the aerosols relative to the clouds and the amount of incoming solar radiation. The high surface albedo in the Arctic regions causes the $\mathrm{BC}$ radiative forcing to be large in this area, despite the smaller BC burden (see Fig. 1). The forcing effiency (RF normalized to burden change) is thus significantly higher in the Arctic $\left(3600 \mathrm{~W} \mathrm{~g}^{-1}\right)$ than at midlatitudes (and $2300 \mathrm{~W} \mathrm{~g}^{-1}$ ). In the fully coupled simulations there can be a small radiative forcing outside the region where the $\mathrm{BC}$ concentrations are scaled up (i.e. the ARC or the MID region), because of the changes in surface and cloud albedo and redistribution of $\mathrm{BC}$ due to changes in circulation and scavenging rates. The indirect effect of $\mathrm{BC}$ aerosols is largest over the oceans, and is much smaller than the direct radiative effects of $\mathrm{BC}$.

Figure 4 shows the monthly mean $\mathrm{BC}$ direct radiative forcing at TOA for the ARC experiment $\left(60-90^{\circ} \mathrm{N}\right.$ average) and the MID experiment $\left(28-60^{\circ} \mathrm{N}\right.$ average). The forcing peaks in May in the Arctic $\left(15 \mathrm{~W} \mathrm{~m}^{-2}\right)$ for several reasons; the solar insolation and the $\mathrm{BC}$ concentrations are both close to their maxima, and it is early in the melt season, with still a great amount of snow and ice-covered surface with a high surface albedo. May is one of the months when the modeled $\mathrm{BC}$ concentrations are underestimated compared to observations (see Fig. 2). During the polar night, the Arctic forcing approaches zero. The mid latitude forcing peaks in the summer, but is still fairly high during the winter months, due to a combination of higher solar radiation in the mid-latitudes compared to the Arctic, as well as higher BC emissions and
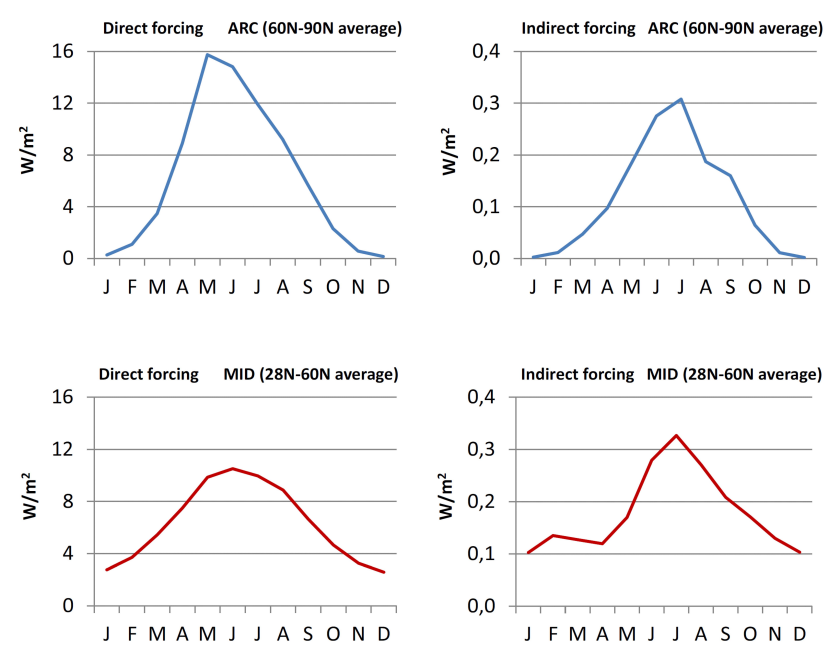

Fig. 4. Monthly mean direct forcing (left) and indirect forcing (right) at the TOA for the ARC-CONTROL $60-90^{\circ} \mathrm{N}$ average (top) and the MID-CONTROL $28-60^{\circ} \mathrm{N}$ average (bottom). All units in $\mathrm{W} \mathrm{m}{ }^{-2}$.

surface albedo in the mid-latitudes during winter compared to the summer season.

\section{Climate response}

The next section show figures from the fully coupled runs, in which the $\mathrm{BC}$ aerosols are allowed to affect the meteorology. The change in the vertical temperature profile for the ARC and the MID experiment is shown in Fig. 5. In both experiments the temperature increases above $800 \mathrm{hPa}$ in the Arctic. The maximum temperature increase is found around $200 \mathrm{hPa}$, in the latitude band where the $\mathrm{BC}$ profile has been scaled up. The temperature increase is larger over a much larger volume of the atmosphere for the MID experiment than for the ARC experiment. In both our experiments the warming in the Arctic is most pronounced in the upper troposphere, but for very different reasons. In the ARC case warming is caused by the direct absorption of solar radiation by $\mathrm{BC}$ in the free troposphere, and further enhanced by semi-direct and surface albedo effects. In the MID experiment the heat is generated by absorption and heating at all altitudes at mid-latitudes, but since the transport to the Arctic mainly follows isentropic surfaces (Hoskins, 1991), the maximum heating in the Arctic is also in this case in the upper troposphere. While there is a warming throughout the troposphere in the MID experiment, the ARC forcing causes a cooling at the surface north of $60^{\circ} \mathrm{N}$, in agreement with the response found by Shindell and Faluvegi (2009).

Figure 6 shows the seasonal cycle for the Arctic temperature response, averaged north of $60^{\circ} \mathrm{N}$ for both the ARC and the MID forcing. The cooling at the surface for the ARC forcing is prominent all year except in the summer 

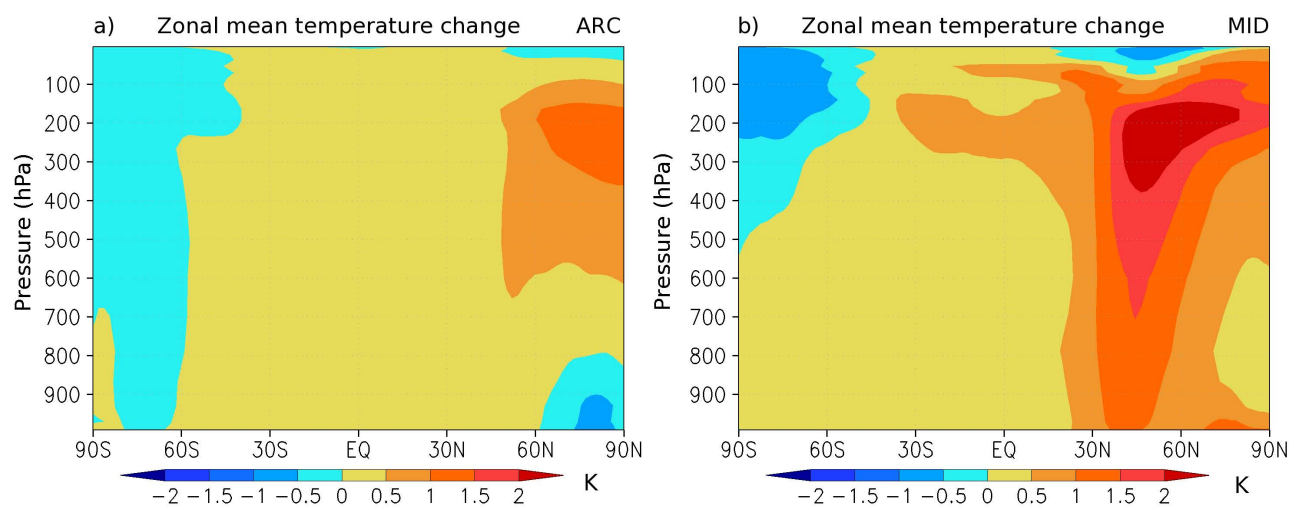

Fig. 5. Zonal annual mean temperature change (in K) for (a) the ARC-CONTROL and (b) the MID-CONTROL.
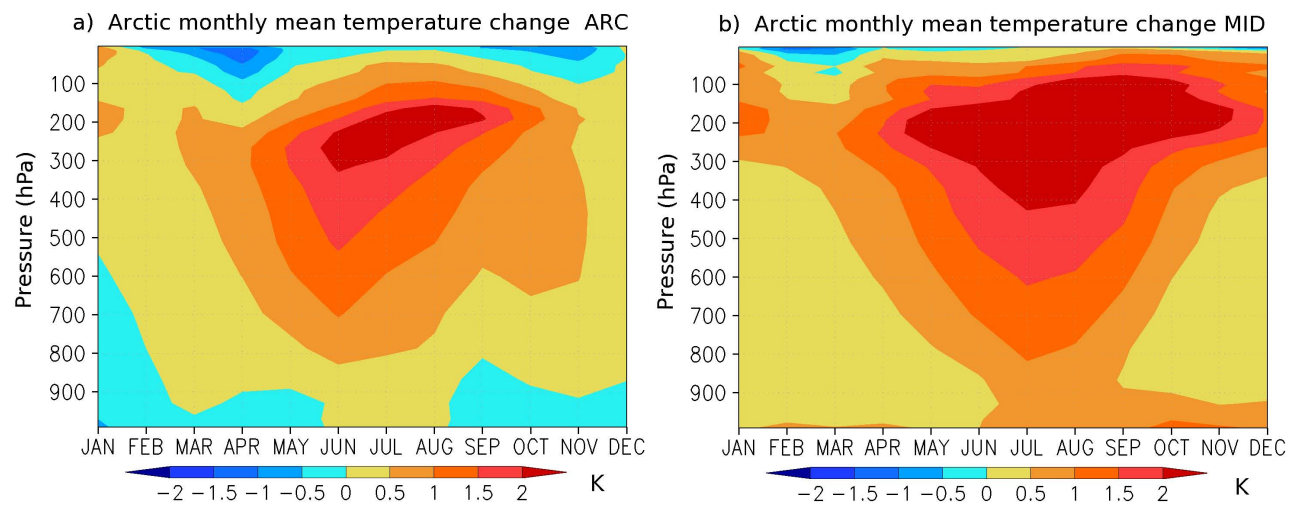

Fig. 6. Monthly Arctic mean $\left(60-90^{\circ} \mathrm{N}\right)$ temperature change (in K) for (a) the ARC-CONTROL and (b) the MID-CONTROL.

months. The warming of the Arctic surface in the summer is likely due to a combined effect of lower static stability during summer/autumn and increased downward longwave radiation and heat fluxes. In both experiments the warming increases rapidly with height, in particular during summer. The period of surface warming is not centered round mid summer in June when the incoming solar radiation is at its maximum, but is slightly shifted towards the autumn when the snow/seaice cover in the Arctic is at its minimum. For the MID forcing the surface warming is strongest during summer and autumn. The warming in the upper troposphere has a maximum during summer and early autumn. It is worth noting that even in the MID case where there is no local forcing in the free troposphere due to enhanced absorption by BC, there is a comparable vertical gradient in the warming as in the ARC case and thus an increase in the static stability.

The geographical distribution of the annual mean SAT response from the ARC and the MID forcing is shown in Fig. 7. The Arctic annual mean SAT response is $-0.4 \mathrm{~K}$ for the ARC forcing with a cooling over most of the Arctic Ocean and a warming over Greenland. There is a maximum cooling $2 \mathrm{~K}$ over the Barents Sea. For the MID forcing the Arctic annual mean SAT response is $1.1 \mathrm{~K}$ with a warming across the entire Arctic Ocean and with a maximum warming of $2 \mathrm{~K}$ over the Barents Sea. This area along the sea-ice edge is the area with particularly large climate variability and large local feedbacks. Our results in general agree with the response in SAT from BC forcing in Shindell and Faluvegi (2009). Shindell and Faluvegi estimated an Arctic SAT response per unit global forcing of $-1.2 \mathrm{~K} \mathrm{~W}^{-1} \mathrm{~m}^{2}$ from $\mathrm{BC}$ aerosols in the Arctic and $0.8 \mathrm{~K} \mathrm{~W}^{-1} \mathrm{~m}^{2}$ Arctic SAT response from BC aerosols in the mid latitudes. Our estimated Arctic SAT response per unit global forcing is $-1.1 \mathrm{~K} \mathrm{~W}^{-1} \mathrm{~m}^{2}$ from BC aerosols in the Arctic and $0.7 \mathrm{~K} \mathrm{~W}^{-1} \mathrm{~m}^{2}$ from $\mathrm{BC}$ aerosols in the mid latitudes, respectively. The global SAT response per unit global forcing is $0.2 \mathrm{~K} \mathrm{~W}^{-1} \mathrm{~m}^{2}$ for both experiments, in accordance with Shindell and Faluvegi.

Shindell and Faluvegi explained the negative surface temperature response mainly as a result of a reduction in the pole-ward heat flux following local heating by absorbing BC aerosols. However, there are also significant changes in the surface energy fluxes due to direct and semi-direct effects of the $\mathrm{BC}$ aerosols as well as local feedbacks.

Through a number of factors BC aerosols may affect the cloud cover in the Arctic, including different semi-direct effects like changes in the static stability or "burn-off" effects, or changes related to a general climate impulse, including changes in surface fluxes, surface albedo and heat transport. 

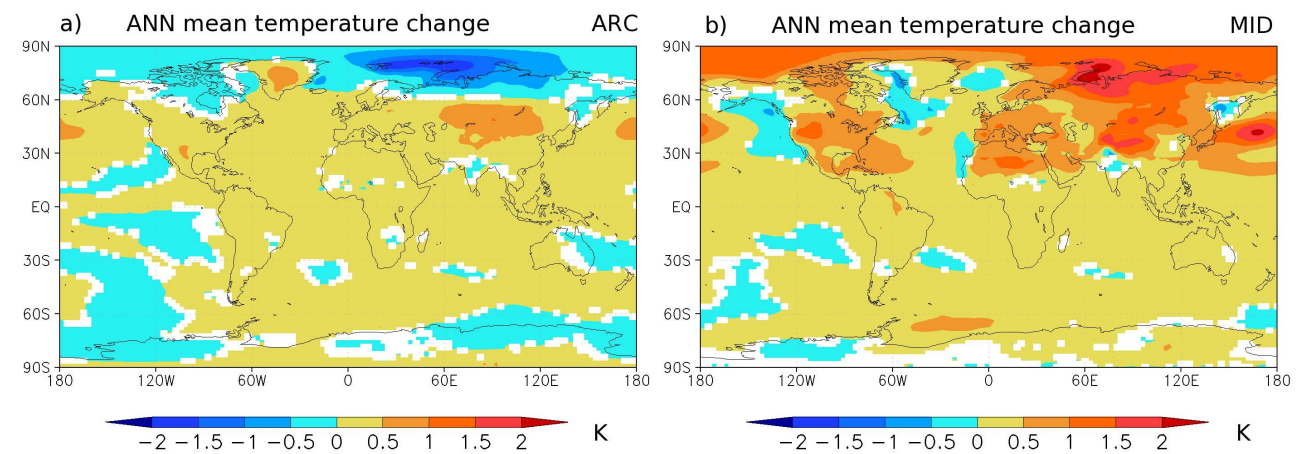

Fig. 7. Annual mean surface air temperature change (in K) for (a) the ARC-CONTROL and (b) the MID-CONTROL. White areas are not significant on a $95 \%$ level.

The Arctic monthly mean total cloud cover is shown in Fig. 8. Both experiments show an increase in the Arctic total cloud cover during summer when the cloud fraction is peaking. The increase is related to low clouds. For the ARC experiment there is a reduction in the high clouds from April to October. The decrease in the high cloud cover in Arctic for the ARC experiment during the seasons with solar radiation available may indicate a burn-off effect, while the increase in low clouds may be due to changes in the surface temperatures, as both experiments show an increase in the low cloud cover during summer when the surface temperature change is positive. In addition a stabilizing effect by the $\mathrm{BC}$ aloft in the ARC experiment may have contributed in this experiment. Kay and Gettelman (2009) found, using observations and atmospheric reanalysis, that near-surface static stability and surface cover can exert significant control on low Arctic cloud presence. It is worth noting that the Arctic clouds in the model are too optically thick because they have excessive liquid water paths when compared to observations (de Boer et al., 2011; Kay et al., 2012b). Too high amounts of cloud water in the model may suppress the aerosol indirect effect.

The geographical distribution of the annual mean cloud cover fraction for low and high clouds is shown in Fig. 9. Both experiments show a decrease in the high cloud cover in the latitude band where BC is scaled up. The cloud cover decreases over the Barents Sea in the ARC experiment, associated with the increase in sea ice and cooling of the surface in this area. The cloud cover increases in most parts in the Arctic for the MID experiment both for low and high clouds. At mid latitudes there is a reduction in the low clouds over land areas. The low cloud cover increases over the oceans. Over the oceans, the $\mathrm{BC}$ aerosols are located higher up in the atmosphere and may enhance the underlying stratocumulus clouds, by stabilizing the atmosphere beneath, and reduce mixing with dry air above (Johnson et al., 2004).

The geographical distribution of the changes in the sea-ice cover is shown in Fig. 10. For the ARC forcing there is an increase in the sea-ice cover, increasing the surface albedo. The geographical pattern closely resembles the geographical

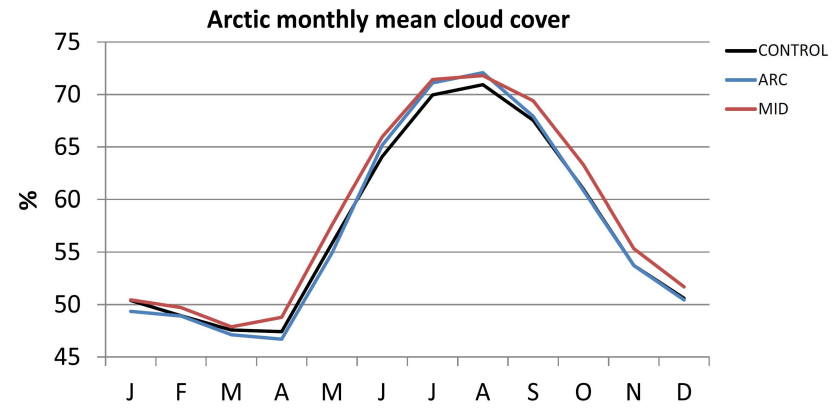

Fig. 8. Monthly Arctic mean cloud cover (in \%) for the CONTROL run (black), the ARC experiment (blue) and the MID experiment (red).

patterns of the surface temperature response. For the MID forcing there is a corresponding decrease in the sea-ice cover.

\section{Heat budget analysis}

A perturbation to the atmospheric concentrations of absorbing aerosols leads to a radiative forcing and a climate response as described above. The full climate response can be analyzed in terms of forcing specific fast responses and general climate feedbacks. The fast response or rapid adjustment refers to the adjustment of the stratosphere, troposphere and the land surface before any change in annual-mean surface temperature $\left(\Delta T_{\mathrm{S}}\right)$ occurs. The response that depends on $\Delta T_{\mathrm{S}}$ is called the slow response or feedback and is usually represented as change in the specific variable per unit $\Delta T_{\mathrm{S}}$ (Hansen et al., 2005; Bala et al., 2010). In the case of absorbing aerosols the fast response include semi-direct and indirect cloud effects. At high latitudes even parts of the response in the sea-ice cover could be due to a fast response as the energy balance of the ice is not only determined by heat conduction from the atmosphere and sea water, but also by the surface radiation budget. Hansen et al. (2005) suggested quantifying the fast responses by looking at the difference between an atmospheric only simulation (approximated by 

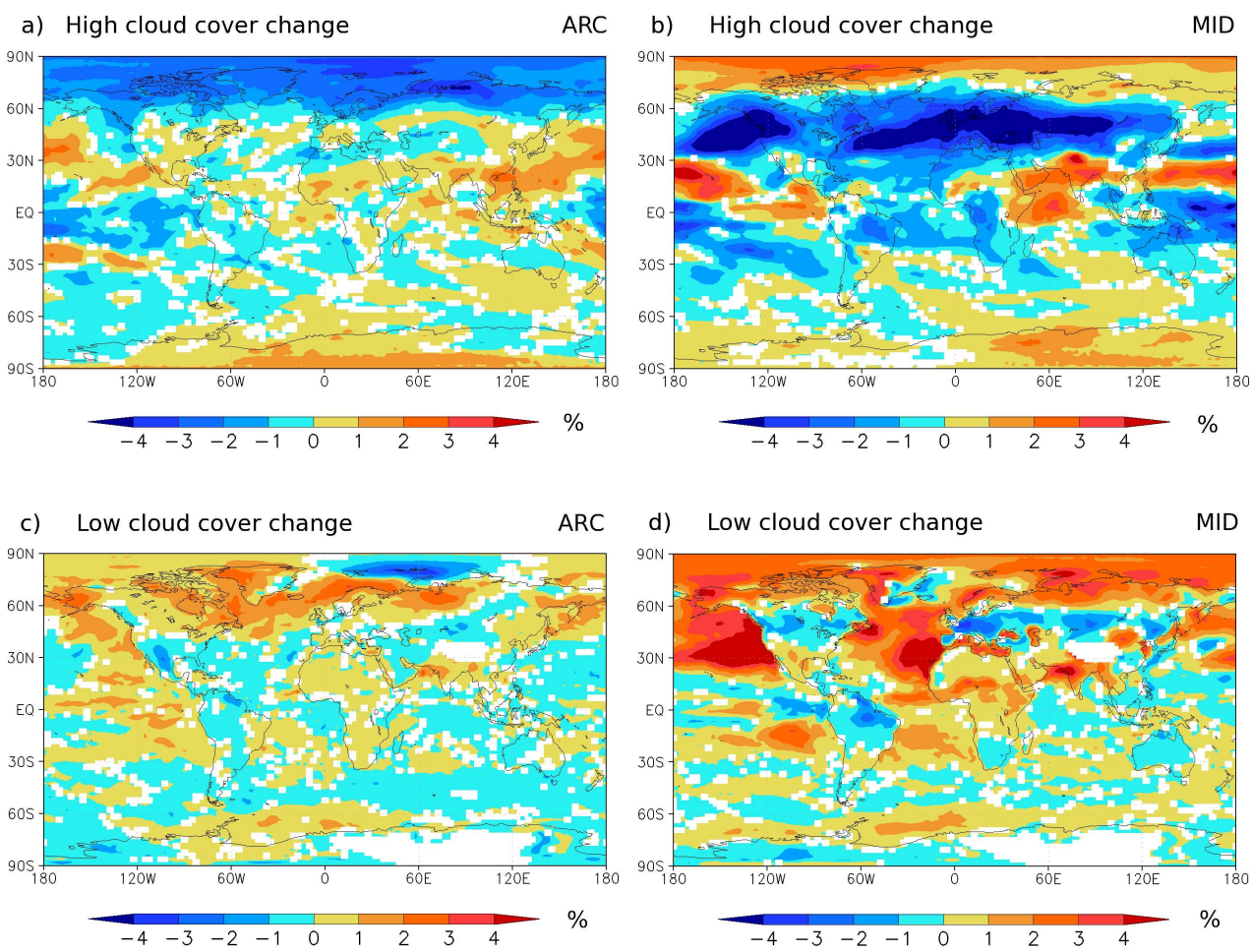

Fig. 9. Annual mean cloud cover change (in \%) for high clouds (top) and low clouds (bottom) for ARC-CONTROL (left) and the MIDCONTROL (right). White areas are not significant on a $95 \%$ level.
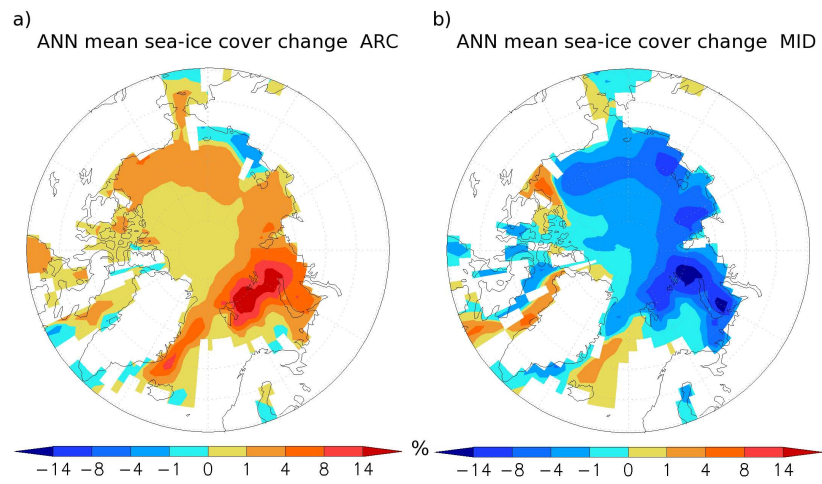

Fig. 10. Annual mean sea-ice cover change (in \%) for (a) the ARCCONTROL and (b) the MID-CONTROL. White areas are not significant on a $95 \%$ level.

a simulation with fixed SSTs) and the response in the fully coupled system.

In the study presented here we have not performed an atmospheric only simulation and it is therefore not possible to identify to what extent the responses are pure feedbacks in the system. The Arctic is a region with potentially strong feedbacks through snow/ice-albedo relation. This feedback mechanism is certainly operative in the model. However, we can not rule out the possibility that in the regions where surface cooling occur and sea ice extent increase this can be caused by reduction in net radiation to the surface through direct forcing and fast responses followed by increased sea ice extent and then reduced $\Delta T_{\mathrm{S}}$ through decreased fluxes of sensible and latent heat. In the cause-effect chain described above, the increase in sea ice will through the feedback loop further decrease $\Delta T_{\mathrm{S}}$, but it may not be initialized by a change in $\Delta T_{\mathrm{S}}$.

Despite the positive $\mathrm{BC}$ forcing at TOA and the heating of the air in the free troposphere, the surface temperature response in the Arctic is negative for the ARC forcing, and positive for the MID forcing. To analyze how BC aerosols affect the Arctic climate, we have calculated the energy budget for the Arctic atmosphere. A summary of the change in the annual mean energy budget terms for the two experiments is given Fig. 11. The terms are positive at TOA when the atmosphere gains energy and positive at the surface when the surface gains energy. Note that all changes in the budget terms are the response to a combination of forcing, fast responses and feedbacks in the Arctic region. For the ARC experiment, the primary forcing through the absorption of solar radiation by the $\mathrm{BC}$ aerosols is the main cause for the increase in the net downward SW flux of $5.4 \mathrm{~W} \mathrm{~m}^{-2}$ at the TOA. The associated warming of the air in the free troposphere and changes in clouds and surface properties lead to an increase in the outgoing LW flux at TOA of $1.2 \mathrm{~W} \mathrm{~m}^{-2}$ (thus the negative change in Fig. 11). The net radiative effect, including clouds and aerosol feedbacks (SW-LW) is thus $4.2 \mathrm{~W} \mathrm{~m}^{-2}$ (Arctic 


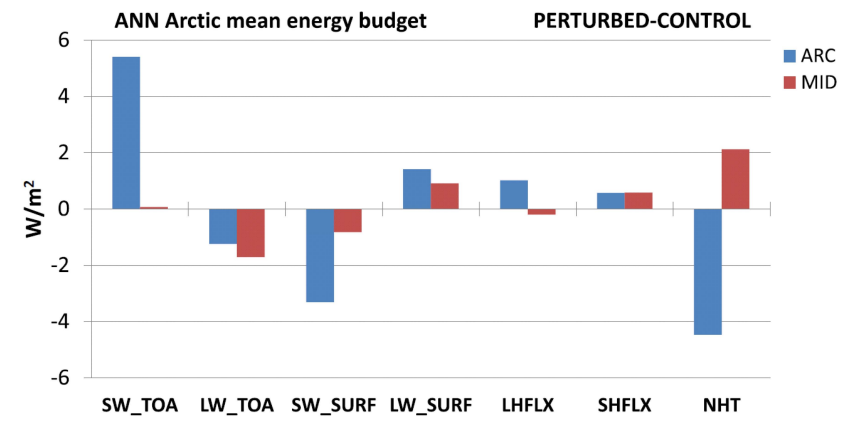

Fig. 11. Difference in the annual mean Arctic atmospheric energy budget terms for the ARC-CONTROL (blue) and MID-CONTROL (red). All units in $\mathrm{W} \mathrm{m}^{-2}$. SW_TOA and LW_TOA are the net SW and LW radiation fluxes at TOA; SW_SURF and LW_SURF are the net SW and LW radiation fluxes at the surface; LHFLX and SHFLX are the latent and sensible heat fluxes and NHT is the net atmospheric heat transport. All units in $\mathrm{W} \mathrm{m}^{-2}$.

average) which, due to the small heat capacity of the air, must be closely balanced by corresponding negative changes in the heat flux at the boundaries (lateral or to the ocean). However, at the surface the net energy budget is $-0.3 \mathrm{~W} \mathrm{~m}^{-2}$, meaning that in the ARC case the NHT in the atmosphere must be reduced. At the surface, there is a significant reduction in the downward SW flux of $3.3 \mathrm{~W} \mathrm{~m}^{-2}$ due to the dimming effect of the absorption by the $\mathrm{BC}$ aerosols in the ARC case. Increased cloudiness and surface albedo may also contribute to the reduction in the net downward SW flux at the surface. The decrease in the NHT for the ARC case is likely to be a result of the increase in the temperatures in the upper Arctic troposphere, decreasing the meridional temperature gradient.

For the MID experiment the primary forcing is located outside the Arctic region, and the change in the net SW flux at the TOA is small, even if there is a consistent increase in the cloud fraction over the Arctic (Fig. 8). However, the heating of the free troposphere by increased NHT and the increase in surface temperatures lead to an increase in the outgoing $\mathrm{LW}$ radiation at TOA which is larger than in the ARC case $\left(1.7 \mathrm{~W} \mathrm{~m}^{-2}\right.$ vs. $\left.1.2 \mathrm{~W} \mathrm{~m}^{-2}\right)$. For the MID forcing the change in the NHT is positive, consistent with the positive temperature response in the mid-latitudes, increasing the meridional temperature gradient between the mid-latitudes and the Arctic, and increasing the heat transport into the Arctic.

Figure 12 shows the seasonal cycle of the changes in the Arctic mean SW and LW radiative fluxes at the TOA for the two perturbed experiments. The seasonal cycle in the TOA radiative imbalance ( $\mathrm{SW}+\mathrm{LW}$, grey curves) is very different in the two experiments. In the ARC case it is positive and follows the seasonal cycle in the primary forcing (SW) with a sharp peak in late spring (May), while in the MID case it is negative mainly through the changes in the LW fluxes and with a much broader maximum during late summer and fall. The change in the Arctic mean SW flux is close to zero for

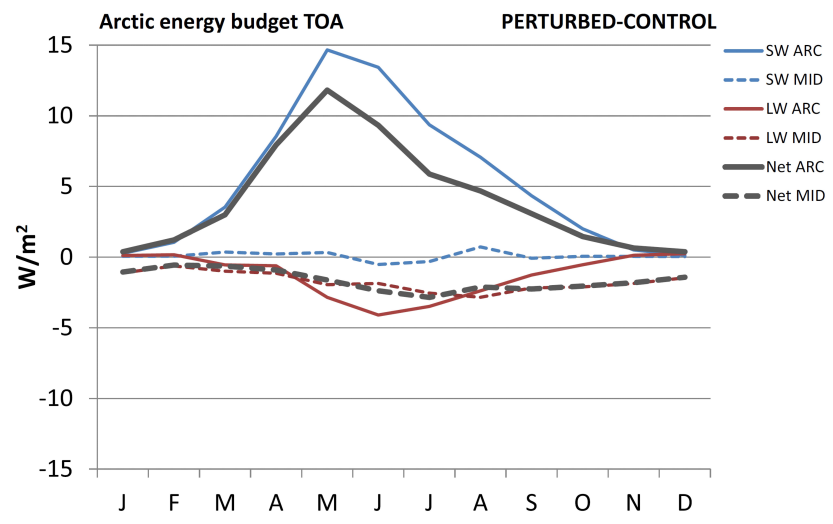

Fig. 12. Changes in the Arctic monthly mean radiative fluxes TOA; incoming SW (blue), outgoing LW (red) and net (black) for the ARC-CONTROL (solid) and MID-CONTROL (dashed). All units in $\mathrm{W} \mathrm{m}^{-2}$.

the MID experiment. This is due to a balance between the increase in albedo due to increased cloud cover (Fig. 8) and the decrease in albedo due to less sea ice (Fig. 10) and snow cover (not shown). The outgoing LW radiation increases for both runs, consistent with the higher temperatures in the free troposphere. The increase in the outgoing LW radiation is largest during the summer season for both runs, when the temperatures are peaking. For the MID forcing the increase in outgoing $\mathrm{LW}$ radiation is prominent all year.

Figure 13 shows the seasonal cycle of the Arctic mean energy fluxes at the surface for the control run (top) and for the change in the fluxes between the control run and the two experiments (bottom). The net SW flux decreases for both experiments, with the largest decrease in the ARC experiment during summer $\left(-9 \mathrm{~W} \mathrm{~m}^{-2}\right)$. The decrease in the net SW flux means that less radiation is reaching the surface, consistent with increased SW absorption by BC higher up in the atmosphere and increased cloudiness, and/or an increase in the amount of reflected radiation from the surface, due to the higher surface albedo. The decrease in annual downwelling solar radiation is twice as large for the ARC experiment as for the MID experiment $\left(5 \mathrm{~W} \mathrm{~m}^{-2}\right.$ vs. $\left.2.6 \mathrm{~W} \mathrm{~m}^{-2}\right)$. Even though the surface albedo increases in the ARC experiment, the net change in the reflected SW flux is negative because the total amount of radiation reaching the surface is smaller. The MID run shows an increase in the net SW flux in the areas with decreased sea-ice, consistent with increased absorption of SW by the exposed darker ocean in a warmer climate, and a decrease in areas with increased cloudiness. Thus, averaged over the Arctic domain the change in SW flux in the MID experiment is negative.

The net longwave flux at the surface increase for both experiments, which means that more longwave radiation is transferred to the surface from the atmosphere. The factors causing this change are changes in the air temperature and cloudiness as well as the surface temperatures and sea-ice 

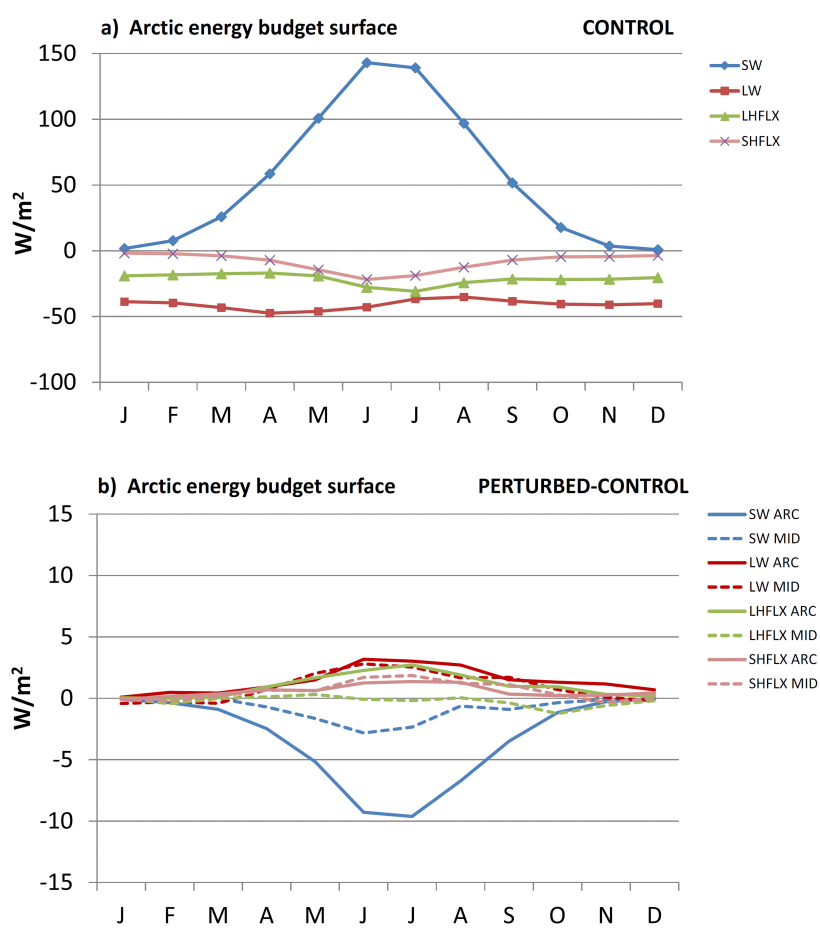

Fig. 13. Seasonal cycle of the Arctic mean energy fluxes at the surface for (a) the CONTROL run and (b) the changes in the radiative fluxes ARC-CONTROL (solid) and MID-CONTROL (dashed); net $\mathrm{SW}$ radiation (blue); net $\mathrm{LW}$ radiation (red); latent heat flux (green) and sensible heat flux (pink). All units in $\mathrm{W} \mathrm{m}^{-2}$.

cover. For the MID experiment there is decreased net longwave flux at the sea-ice-edge where more long wave radiation is emitted to the atmosphere when the sea-ice melts.

In the reference run, the sensible heat flux is positive downward over the Arctic Ocean, associated with the temperature inversion caused by the net radiative energy loss from the surface. Averaged over $60-90^{\circ} \mathrm{N}$ however, the sensitive heat flux is negative downward (more energy from the surface to the atmosphere). The change in the Arctic mean sensible heat flux is slightly positive downward for both experiments, which means that more energy is transported from the atmosphere to the surface. The latent heat flux increases downward for the ARC experiment, consistent with the colder surface temperatures, while the latent heat flux is slightly reduced downward during autumn for the MID experiment. During the summer months, the longwave radiative flux and the heat fluxes for the ARC experiment have a maximum (more flux to the surface).

\section{Summary and discussion}

There is no straightforward one-to-one relationship between the radiative forcing and the temperature response at a given location, as have been shown in previous studies (Boer and
Yu, 2003; Shindell and Faluvegi, 2009). BC aerosols heat the surrounding air and alter the local static stability in the atmosphere. Regional changes in the $\mathrm{BC}$ concentration also change the temperature gradients affecting the meridional heat transport. Using the NorESM model we find that when $\mathrm{BC}$ concentrations are scaled up in the Arctic according to its current vertical profile, the regional surface temperature response is negative despite a positive radiative forcing at TOA. The Arctic surface temperature response is similar to the results found in Shindell and Faluvegi (2009). We find that the $\mathrm{BC}$ climate response has a regional nature and this regionality is likely linked to sea ice loss. The surface cooling can be explained by a combination of changes in the vertical fluxes of heat and radiation, cloud cover and a reduction in the meridional heat transport from lower latitudes. There is an upper troposphere heating by absorption of SW radiation, a surface dimming effect that reduces the downwelling solar radiation, a decrease in the high cloud cover and an increase in the low cloud cover. The reduction in the meridional heat transport is likely caused by a reduction in the meridional temperature gradient. Even though BC aerosols are mainly emitted in the mid-latitudes and only a small fraction enter the Arctic, they may impact the Arctic climate. We estimate that $\mathrm{BC}$ aerosols at mid-latitudes lead to increased transport of heat into the Arctic, causing a warming, both at the surface and in the atmospheric. The largest increase in the temperatures is found in the upper troposphere during summer due to transport of heat along isentropic surfaces. In this case the temperature response is enhanced through snow/ice albedo feedback. In a recent study, Allen et al. (2012) argued that $\mathrm{BC}$ and tropospheric ozone are the main drivers of the Northern Hemisphere Hadley cell expansion, by heating primarily in the mid latitudes, causing a poleward shift in the storms tracks. In our study we also find a poleward shift of the jet stream for the MID experiment with local warming at mid latitudes (not shown).

It should be noted that the NorESM model has a relatively low climate sensitivity compared to most other climate models (Andrews et al., 2012). Iversen et al. (2012) calculate the forcing from $4 \times \mathrm{CO}_{2}$ to $6.3 \mathrm{~W} \mathrm{~m}^{-2}$ and the global temperature response to $5.7 \mathrm{~K}$ in NorESM using the Gregory linear regression method (Gregory et al., 2004). The equilibrium climate sensitivity is calculated to be slightly smaller than $2.9 \mathrm{~K}$, and the transient climate response is below $1.4 \mathrm{~K}$. Possible explanations for the low sensitivity are relatively large cloud feedbacks and a strong Atlantic meridional overturning circulation in the model (Iversen et al., 2012).

Compared to observations, the model clearly underestimates BC concentrations at the surface, but there are also indications that the model overestimates the BC concentrations in the upper troposphere in the Arctic. This bias may enhance the vertical response pattern we see in the Arctic for the $\mathrm{ARC}$ run. The temperature response to the $\mathrm{BC}$ forcing depends on the vertical distribution of the $\mathrm{BC}$ aerosols. In idealized climate simulations Ban-Weiss et al. (2011) showed 
that as the altitude of the $\mathrm{BC}$ increases, the surface temperature response decreases. In this study we have scaled up the background vertical profile of the $\mathrm{BC}$ aerosols in the model, where most of the Arctic $\mathrm{BC}$ aerosols are located in the free troposphere. If the emissions of $\mathrm{BC}$ aerosols in the Arctic are increased in the future, e.g. by increased shipping or oil production, the $\mathrm{BC}$ aerosols would be emitted directly into the Arctic planetary boundary layer and a different temperature response might be evident. The $\mathrm{BC}$ aerosols in the planetary boundary layer would have a stronger interaction with the surface, both by deposition of BC on snow and ice and by radiative and sensible heat fluxes down to the surface. In such a model study it would be important to include the effect of the deposition of BC on snow and sea-ice covered surfaces.

Our idealized model calculations indicate that atmospheric $\mathrm{BC}$ forcing outside the Arctic may be more important for the Arctic climate change compared to the forcing in the Arctic itself (with the linear assumption that the $10 \times \mathrm{BC}$ response is scalable down to $1 \times \mathrm{BC}$ ). Although the albedo effect of $\mathrm{BC}$ on snow does show a more regional response to an Arctic forcing, these results suggest that mitigation strategies for the Arctic climate should also address BC sources in locations outside the Arctic even if they do not contribute much to BC in the Arctic.

Acknowledgements. We thank two anonymous reviewers for useful comments and to help increase the quality of the paper. We thank the Aerosol groups at the National Oceanic and Atmospheric Administration (NOAA), Global Monitoring Division for providing measurement data from Barrow, Konstantinos Eleftheriadis and Sterios Vratolis at the Institute of Nuclear Technology and Radiation Protection for providing measurement data from Zeppelin and Sangeeta Sharma at Environmental Canada for providing measurement data from Alert. We acknowledge the EBAS (http://ebas.nilu.no/Default.aspx), the NOAA ESRL (http://www.esrl.noaa.gov/gmd) and the EMEP (http://www.emep.int) databases. This study was partly funded by the Research Council in Norway through the Earthclim project, the Norwegian research Council's Programme for supercomputing (NOTUR) through a grant for computing time, and the ACCESS project supported by the European Commission 7th Framework Programme. The CESM project is supported by the National Science Foundation and the Office of Science (BER) of the US Department of Energy. The National Center for Atmospheric Research is operated by the University Corporation for Atmospheric Research under sponsorship of the National Science Foundation.

Edited by: R. Krejci

\section{References}

Albrecht, B. A.: Aerosols, cloud microphysics, and fractional cloudiness, Science, 245, 1227-1230, 1989.

Allen, R. J., Sherwood, S. C., Norris, J. R., and Zender, C. S.: Recent Northern Hemisphere tropical expansion primarily driven by black carbon and tropospheric ozone, Nature, 485, 350-354, 2012.

AMAP: Snow, Water, Ice and Permafrost in the Arctic (SWIPA): Climate Change and the Cryosphere. Arctic Monitoring and Assessment Programme (AMAP), Oslo, xii + 538 pp., 2011a.

AMAP: The Impact of Black Carbon on Arctic Climate, by: Quinn, P. K., Stohl, A., Arneth, A., Berntsen, T., Burkhart, J. F., Christensen, J., Flanner, M., Kupiainen, K., Lihavainen, H., Shepherd, M., Shevchenko, V., Skov, H., and Vestreng, V.: Arctic Monitoring and Assessment Programme (AMAP), Oslo, 72 pp., $2011 \mathrm{~b}$.

Andrews, T., Gregory, J. M., Webb, M. J., and Taylor, K. E.: Forcing, feedbacks and climate sensitivity in CMIP5 coupled atmosphere-ocean climate models, Geophys. Res. Lett., 39, L09712, doi:10.1029/2012g1051607, 2012.

Bala, G., Caldeira, K., and Nemani, R.: Fast versus slow response in climate change: implications for the global hydrological cycle, Clim. Dynam., 35, 423-434, 2010.

Ban-Weiss, G. A., Cao, L., Bala, G., and Caldeira, K.: Dependence of climate forcing and response on the altitude of black carbon aerosols, Clim. Dynam., 38, 1-15, 2011.

Barrie, L. A.: Arctic air pollution: an overview of current knowledge, Atmos. Environ., 20, 643-663, 1986.

Bauer, S. E., Menon, S., Koch, D., Bond, T. C., and Tsigaridis, K.: A global modeling study on carbonaceous aerosol microphysical characteristics and radiative effects, Atmos. Chem. Phys., 10, 7439-7456, doi:10.5194/acp-10-7439-2010, 2010.

Bentsen, M., Bethke, I., Debernard, J. B., Iversen, T., Kirkevåg, A., Seland, Ø., Drange, H., Roelandt, C., Seierstad, I. A., Hoose, C., and Kristjánsson, J. E.: The Norwegian Earth System Model, NorESM1-M - Part 1: Description and basic evaluation, Geosci. Model Dev. Discuss., 5, 2843-2931, doi:10.5194/gmdd-5-28432012, 2012.

Boer, G. J. and Yu, B.: Climate sensitivity and response, Clim. Dynam., 20, 415-429, doi:10.1007/s00382-002-0283-3, 2003.

Chung, C. E., Ramanathan, V., and Decremer, D.: Observationally constrained estimates of carbonaceous aerosol radiative forcing, P. Natl. Acad. Sci. USA, 109, 11624-11629, doi:10.1073/pnas.1203707109, 2012.

de Boer, G., Chapman, W., Kay, J., Medeiros, B., Shupe, M. D., Vavrus, S. and Walsh, J.: A characterization of the present-day Arctic atmosphere in CCSM4, J. Climate, 25, 2676-2695, 2011.

Eleftheriadis, K., Vratolis, S., and Nyeki, S.: Aerosol black carbon in the European Arctic: measurements at Zeppelin station, Ny-Ålesund, Svalbard from 1998-2007, Geophys. Res. Lett., 36, L02809, doi:10.1029/2008GL035741, 2009.

Flanner, M., Zender, C., Randerson, J. and Rasch, P.: Present-day climate forcing and response from black carbon in snow, J. Geophys. Res., 112, D11202, doi:10.1029/2006JD008003, 2007.

Forster, P., Ramaswamy, V., Artaxo, P., Berntsen, T., Betts, R., Fahey, D. W., Haywood, J., Lean, J., Lowe, D. C., Myhre, G., Nganga, J., Prinn, R., Raga, G., Schulz M., and Van Dorland, R.: Changes in Atmospheric Constituents and in Radiative Forcing, in: Climate Change 2007: The Physical Science Basis. Contribution of Working Group I to the Fourth Assessment Report 
of the Intergovernmental Panel on Climate Change, edited by: Solomon, S., Qin, D., Manning, M., Chen, Z., Marquis, M., Averyt, K. B., Tignor, M., and Miller, H. L., Cambridge University Press, Cambridge, United Kingdom and New York, NY, USA, 2007.

Furevik, T., Bentsen, M., Drange, H., Kindem, I., Kvamstø, N. G., and Sorteberg, A.: Description and evaluation of the Bergen climate model: ARPEGE coupled with MICOM, Clim. Dynam., 21, 27-51, 2003.

Gent, P. R., Danabasoglu, G., Donner, L. J., Holland, M. M., Hunke, E. C., Jayne, S. R., Lawrence, D. M., Neale, R. B., Rasch, P. J., Vertenstein, M., Worley P. H., Yang, Z.-L., and Zhang, M.: The community climate system model version 4, J. Climate, 24, 4973-4991, 2011.

Gregory, J. M., Ingram, W. J., Palmer, M. A., Jones, G. S., Stott, P. A., Thorpe, R. B., Lowe, J. A., Johns, T. C., and Williams, K. D.: A new method for diagnosing radiative forcing and climate sensitivity, Geophys. Res. Lett., 31, L03205, doi:10.1029/2003GL018747, 2004.

Hansen, J. and Nazarenko, L.: Soot climate forcing via snow and ice albedos, P. Natl. Acad. Sci. USA, 101, 423-428, 2004.

Hansen, J., Sato, M., and Ruedy, R.: Radiative forcing and climate response, J. Geophys. Res., 102, 6831-6864, 1997.

Hansen, J., Sato, M., Ruedy, R., Lacis, A., and Oinas, V.: Global warming in the twenty-first century: An alternative scenario, $\mathrm{P}$. Natl. Acad. Sci. USA, 97, 9875-9880, 2000.

Hansen, J., Sato, M., Ruedy, R., Nazarenko, L., Lacis, A., Schmidt, G. A., Russell, G., Aleinov, I., Bauer, M., Bauer, S., Bell, N., Cairns, B., Canuto, V., Chandler, M., Cheng, Y., Del Genio, A., Faluvegi, G., Fleming, E., Friend, A., Hall, T., Jackman, C., Kelley, M., Kiang, N., Koch, D., Lean, J., Lerner, J., Lo, K., Menon, S., Miller, R., Minnis, P., Novakov, T., Oinas, V., Perlwitz, J., Perlwitz, J., Rind, D., Romanou, A., Shindell, D., Stone, P., Sun, S., Tausnev, N., Thresher, D., Wielicki, B., Wong, T., Yao, M., and Zhang, S.: Efficacy of climate forcings, J. Geophys. Res., 110, D18104, doi:10.1029/2005JD005776, 2005.

Hoose, C., Kristjànsson, J. E., Iversen, T., Kirkevåg, A., Seland, Ø., and Gettelman, A.: Constraining cloud droplet number concentration in GCMs suppresses the aerosol indirect effect, 20, Geophys. Res. Lett., 36, L12807, doi:10.1029/2009GL038568, 2009.

Hoskins, B. J.: Towards a PV- $\theta$ view of the general circulation, Tellus A, 43, 27-35, 1991.

Hwang, Y. T., Frierson, D. M. W., and Kay, J. E.: Coupling between Arctic feedbacks and changes in poleward energy transport, Geophys. Res. Lett., 38, L17704, doi:10.1029/2011GL048546, 2011.

IPCC: Climate change 2007: the physical science basis: contribution of Working Group I to the Fourth Assessment Report of the Intergovernmental Panel on Climate Change, Cambridge Univ Pr, Cambridge, United Kingdom and New York, NY, USA, 2007.

Iversen, T., Bentsen, M., Bethke, I., Debernard, J. B., Kirkevåg, A., Seland, Ø., Drange, H., Kristjánsson, J. E., Medhaug, I., Sand, M., and Seierstad, I. A.: The Norwegian Earth System Model, NorESM1-M - Part 2: Climate response and scenario projections, Geosci. Model Dev. Discuss., 5, 2933-2998, doi:10.5194/gmdd-5-2933-2012, 2012.

Jacobson, M. Z.: Short-term effects of controlling fossil-fuel soot, biofuel soot and gases, and methane on climate, Arctic ice, and air pollution health, J. Geophys. Res., 115, D14209, doi:10.1029/2009JD013795, 2010.
Johnson, B. T., Shine, K. P., and Forster, P. M.: The semi-direct aerosol effect: Impact of absorbing aerosols on marine stratocumulus, Q. J. Roy. Meteor. Soc., 130, 1407-1422, 2004.

Kay, J. E. and Gettelman, A.: Cloud influence on and response to seasonal Arctic sea ice loss, J. Geophys. Res, 114, D18204, doi:10.1029/2009JD011773, 2009.

Kay, J. E., Holland, M. M., Bitz, C. M., Blanchard-Wrigglesworth, E., Gettelman, A., Conley, A., and Bailey, D.: The influence of local feedbacks and northward heat transport on the equilibrium Arctic climate response to increased greenhouse gas forcing, J. Climate, 25, 5433-5450, doi:10.1175/JCLI-D-1100622.1, 2012a.

Kay, J. E., Hillman, B. R., Klein, S. A., Zhang, Y., Medeiros, B., Pincus, R., Gettelman, A., Eaton, B., Boyle, J., Marchand, R., and Ackerman, T. P.: Exposing global cloud biases in the Community Atmosphere Model (CAM) using satellite observations and their corresponding instrument simulators, J. Climate, 25, 5190-5207, doi:10.1175/JCLI-D-11-00469.1, 2012b.

Kirkevåg, A., Iversen, T., Seland, Ø., Debernard, J., Storelvmo, T. and Kristjánsson, J.: Aerosol-cloud-climate interactions in the climate model CAM-Oslo, Tellus, 60, 492-512, 2008.

Kirkevåg, A., Iversen, T., Seland, Ø., Hoose, C., Kristjánsson, J. E., Struthers, H., Ekman, A. M. L., Ghan, S., Griesfeller, J., Nilsson, E. D., and Schulz, M.: Aerosol-climate interactions in the Norwegian Earth System Model - NorESM, Geosci. Model Dev. Discuss., 5, 2599-2685, doi:10.5194/gmdd-5-2599-2012, 2012.

Koch, D. and Del Genio, A. D.: Black carbon semi-direct effects on cloud cover: review and synthesis, Atmos. Chem. Phys., 10, 7685-7696, doi:10.5194/acp-10-7685-2010, 2010.

Koch, D., Schulz, M., Kinne, S., McNaughton, C., Spackman, J. R., Balkanski, Y., Bauer, S., Berntsen, T., Bond, T. C., Boucher, O., Chin, M., Clarke, A., De Luca, N., Dentener, F., Diehl, T., Dubovik, O., Easter, R., Fahey, D. W., Feichter, J., Fillmore, D., Freitag, S., Ghan, S., Ginoux, P., Gong, S., Horowitz, L., Iversen, T., Kirkevåg, A., Klimont, Z., Kondo, Y., Krol, M., Liu, X., Miller, R., Montanaro, V., Moteki, N., Myhre, G., Penner, J. E., Perlwitz, J., Pitari, G., Reddy, S., Sahu, L., Sakamoto, H., Schuster, G., Schwarz, J. P., Seland, Ø., Stier, P., Takegawa, N., Takemura, T., Textor, C., van Aardenne, J. A., and Zhao, Y.: Evaluation of black carbon estimations in global aerosol models, Atmos. Chem. Phys., 9, 9001-9026, doi:10.5194/acp-9-9001-2009, 2009a.

Koch, D., Menon, S., Del Genio, A., Ruedy, R., Alienov, I., and Schmidt, G. A.: Distinguishing aerosol impacts on climate over the past century, J. Climate, 22, 2659-2677, 2009b.

Lamarque, J.-F., Bond, T. C., Eyring, V., Granier, C., Heil, A., Klimont, Z., Lee, D., Liousse, C., Mieville, A., Owen, B., Schultz, M. G., Shindell, D., Smith, S. J., Stehfest, E., Van Aardenne, J., Cooper, O. R., Kainuma, M., Mahowald, N., McConnell, J. R., Naik, V., Riahi, K., and van Vuuren, D. P.: Historical (1850-2000) gridded anthropogenic and biomass burning emissions of reactive gases and aerosols: methodology and application, Atmos. Chem. Phys., 10, 7017-7039, doi:10.5194/acp10-7017-2010, 2010.

Law, K. S. and Stohl, A.: Arctic air pollution: Origins and impacts, Science, 315, 1537-1540, 2007.

Levy, H. I., Schwarzkopf, M. D., Horowitz, L., Ramaswamy, V., and Findell, K.: Strong sensitivity of late 21 st century climate to projected changes in short-lived air pollutants, J. Geophys. Res., 
113, D06102, doi:10.1029/2007JD009176, 2008.

Liu, J., Fan, S., Horowitz, L. W., and Levy II, H.: Evaluation of factors controlling long-range transport of black carbon to the Arctic, J. Geophys. Res., 116, D04307, doi:10.1029/2010JD015145, 2011.

Lund, M. T. and Berntsen, T.: Parameterization of black carbon aging in the OsloCTM2 and implications for regional transport to the Arctic, Atmos. Chem. Phys., 12, 6999-7014, doi:10.5194/acp-12-6999-2012, 2012.

Menon, S., Hansen, J., Nazarenko, L. and Luo, Y.: Climate effects of black carbon aerosols in China and India, Science, 297, 22502253, 2002.

Myhre, G., Samset, B. H., Schulz, M., Balkanski, Y., Bauer, S., Berntsen, T. K., Bian, H., Bellouin, N., Chin, M., Diehl, T., Easter, R. C., Feichter, J., Ghan, S. J., Hauglustaine, D., Iversen, T., Kinne, S., Kirkevåg, A., Lamarque, J.-F., Lin, G., Liu, X., Luo, G., Ma, X., Penner, J. E., Rasch, P. J., Seland, Ø., Skeie, R. B., Stier, P., Takemura, T., Tsigaridis, K., Wang, Z., Xu, L., Yu, H., Yu, F., Yoon, J.-H., Zhang, K., Zhang, H., and Zhou, C.: Radiative forcing of the direct aerosol effect from AeroCom Phase II simulations, Atmos. Chem. Phys. Discuss., 12, 22355-22413, doi:10.5194/acpd-12-22355-2012, 2012.

Otterå, O. H., Bentsen, M., Bethke, I., and Kvamstø, N. G.: Simulated pre-industrial climate in Bergen Climate Model (version 2): model description and large-scale circulation features, Geosci. Model Dev., 2, 197-212, doi:10.5194/gmd-2-197-2009, 2009.

Porter, D. F., Cassano, J. J., Serreze, M. C., and Kindig, D. N.: New estimates of the large-scale Arctic atmospheric energy budget, J. Geophys. Res., 115, D08108, doi:10.1029/2009JD012653, 2010.

Pueschel, R. F. and Kinne, S. A.: Physical and radiative properties of Arctic atmospheric aerosols, Sci. Total Environ., 160, 811-824, 1995.

Samset, B. H. and Myhre, G.: Vertical dependence of black carbon, sulphate and biomass burning aerosol radiative forcing, Geophys. Res. Lett., 38, L24802, doi:10.1029/2011g1049697, 2011.

Samset, B. H., Myhre, G., Schulz, M., Balkanski, Y., Bauer, S., Berntsen, T. K., Bian, H., Bellouin, N., Diehl, T., Easter, R. C., Ghan, S. J., Iversen, T., Kinne, S., Kirkevåg, A., Lamarque, J.-F., Lin, G., Liu, X., Penner, J., Seland, Ø., Skeie, R. B., Stier, P., Takemura, T., Tsigaridis, K., and Zhang, K.: Black carbon vertical profiles strongly affect its radiative forcing uncertainty, Atmos. Chem. Phys. Discuss., 12, 28929-28953, doi:10.5194/acpd-12-28929-2012, 2012.
Schulz, M., Textor, C., Kinne, S., Balkanski, Y., Bauer, S., Berntsen, T., Berglen, T., Boucher, O., Dentener, F., Guibert, S., Isaksen, I. S. A., Iversen, T., Koch, D., Kirkevåg, A., Liu, X., Montanaro, V., Myhre, G., Penner, J. E., Pitari, G., Reddy, S., Seland, $\emptyset$., Stier, P., and Takemura, T.: Radiative forcing by aerosols as derived from the AeroCom present-day and pre-industrial simulations, Atmos. Chem. Phys., 6, 5225-5246, doi:10.5194/acp-65225-2006, 2006.

Seland, Ø., Iversen, T., Kirkevåg, A., and Storelvmo, T.: Aerosolclimate interactions in the CAM-Oslo atmospheric GCM and investigation of associated basic shortcomings, Tellus A, 60, 459491, 2008.

Sharma, S., Andrews, E., Barrie, L., Ogren, J., and Lavoue, D.: Variations and sources of the equivalent black carbon in the high Arctic revealed by long-term observations at Alert and Barrow: 1989-2003, J. Geophys. Res., 111, D14208, doi:10.1029/2005JD006581, 2006.

Shindell, D.: Local and remote contributions to Arctic warming, Geophys. Res. Lett., 34, L14704, doi:10.1029/2007GL030221, 2007.

Shindell, D. and Faluvegi, G.: Climate response to regional radiative forcing during the twentieth century, Nat. Geosci., 2, 294-300, 2009.

Shindell, D. T., Chin, M., Dentener, F., Doherty, R. M., Faluvegi, G., Fiore, A. M., Hess, P., Koch, D. M., MacKenzie, I. A., Sanderson, M. G., Schultz, M. G., Schulz, M., Stevenson, D. S., Teich, H., Textor, C., Wild, O., Bergmann, D. J., Bey, I., Bian, H., Cuvelier, C., Duncan, B. N., Folberth, G., Horowitz, L. W., Jonson, J., Kaminski, J. W., Marmer, E., Park, R., Pringle, K. J., Schroeder, S., Szopa, S., Takemura, T., Zeng, G., Keating, T. J., and Zuber, A.: A multi-model assessment of pollution transport to the Arctic, Atmos. Chem. Phys., 8, 5353-5372, doi:10.5194/acp-85353-2008, 2008.

Shindell, D., Kuylenstierna, J. C. I., Vignati, E., van Dingenen, R., Amann, M., Klimont, Z., Anenberg, S. C., Muller, N., JanssensMaenhout, G., and Raes, F.: Simultaneously mitigating near-term climate change and improving human health and food security, Science, 335, 183-189, 2012.

Stohl, A., Berg, T., Burkhart, J. F., Fjæraa, A. M., Forster, C., Herber, A., Hov, Ø., Lunder, C., McMillan, W. W., Oltmans, S., Shiobara, M., Simpson, D., Solberg, S., Stebel, K., Ström, J., Tørseth, K., Treffeisen, R., Virkkunen, K., and Yttri, K. E.: Arctic smoke - record high air pollution levels in the European Arctic due to agricultural fires in Eastern Europe in spring 2006, Atmos. Chem. Phys., 7, 511-534, doi:10.5194/acp-7-511-2007, 2007.

Twomey, S.: The in?uence of pollution on the shortwave albedo of clouds, J. Atmos. Sci, 34, 1149-1152, 1977. 